\title{
PENGARUH KONDISI EKONOMI MAKRO DAN PROSES MANAJEMEN RISIKO KREDIT TERHADAP NON-PERFORMING LOAN \\ (Studi Kasus pada Bank X)
}

\author{
Arif Rahman Hakim \\ Jurusan Studi Pembangunan Universitas Brawijaya \\ hakimbasroen@gmail.com
}

\begin{abstract}
Commercial banks is one of the vital industries within a modern economic system. The industry bridges the demands and supplies of money as the most important factor of production in the system. In line with its crucial role, bank's failure may impose a financial crisis within the system when it take place in a systemic way. One of the most common causes for this failure is the high rate of non-performing loan (NPL), a condition where the debtors fail to pay money they borrow from a bank. In spite of the fact that this fail is caused by the dissatisfactory performance of the borrower, external factor such as macroeconomic condition and the internal banking system factor such as credit risk management appear to be the common factors to the crisis. This research tries to reveal the influence of macroeconomic condition and the process of credit risk management on the level of bank's non performing loan by using a statistics modelling test. While the most of studies in the macroeconomics fields focuse the analysis on the secondary time series data, the current research employs primary data from questionnaire to take a closer look the perception of bank's credit analists on the macroeconomic, credit management and NPL issues. The result taken from a case study in Bank X shows that there is a significat impact of macroeconomic condition, whether directly and indirectly through variable credit risk management process, on the degree of bank's non-performing loan.
\end{abstract}

Keywords: macroeconomic, credit management, non-performing loan

\begin{abstract}
ABSTRAK
Industri perbankan komersial merupakan salah satu institusi sentral dalam sistem perekonomian. Industri ini mempertemukan permintaan dan penawaran uang sebagai salah satu faktor produksi dalam sistem perekonomian. Perbankan menjadi isu krusial dalam perekonomian karena kegagalan kinerja sebuah bank dalam sistem perekonomian bisa berdampak pada krisis keuangan jika dampak yang dihasilkan bersifat sistemik. Pada umumnya penyebab kegagalan kinerja perbankan disebabkan oleh tingginya tingkat non-performing loan (NPL) atau gagal bayar oleh para debitur. Faktor gagal bayar ini disamping karena kondisi internal kreditur dapat pula disebabkan oleh faktor eksternal seperti kondisi ekonomi makro atau faktor internal industri perbankan seperti proses manajemen risiko kredit yang diterapkan oleh industri perbankan. Penelitian ini berupaya untuk mengungkap pengaruh kondisi ekonomi makro dan proses manajemen risiko kredit melalui uji model dengan menggunakan perangkat analisis jalur (path analysis) terhadap NPL. Berbeda dengan penelitian-penelitian sebelumnya pada kajian ekonomi makro yang lebih banyak menggunakan data sekunder time series, data pada penelitian ini bersumber dari kuesioner untuk mengukur persepsi analis kredit industri perbankan dengan mengambil studi kasus di Bank X. Hasil penelitian ini menunjukkan adanya pengaruh yang signifikan dari kondisi ekonomi makro baik secara langsung maupun secara tidak langsung melalui variabel proses manajemen risiko kredit terhadap tingkat NPL
\end{abstract}

Kata kunci: Ekonomi makro, manajemen kredit, non-performing loan 


\section{PENDAHULUAN}

Salah satu pokok permasalahan dalam studi ekonomi makro adalah masalah stabilisasi ekonomi dimana lembaga keuangan khususnya perbankan menjadi sektor penting dalam mewujudkan stabilitas dan pertumbuhan ekonomi suatu negara. Beberapa krisis keuangan dunia yang baru-baru ini berlangsung telah menunjukkan bahwa krisis perbankan dapat menjadi pengganggu tatanan sebuah perekonomian (Agnello \& Sousa, 2011). Hal ini telah menarik penelitian-penelitian di bidang ilmu ekonomi untuk memahami faktor-faktor yang berpotensi memicu krisis perbankan. Diantara berbagai hipotesis tentang penyebab krisis perbankan, kondisi ekonomi makro dianggap sebagai faktor yang memainkan peran penting atas krisis perbankan ini (Castro, 2013).

Teorisasi tentang hubungan antara kondisi ekonomi makro dengan krisis perbankan pada umumnya menyatakan bahwa kondisi-kondisi perekonomian yang tidak menguntungkan, seperti halnya tingkat pertumbuhan yang lemah atau bahkan negatif, tingkat pengangguran yang tinggi, suku bunga tinggi, dan laju injflasi tinggi, merupakan situasi yang kondusif bagi terjadinya krisis perbankan (Castro, 2013; Demirguc-Kunt \& Detragiache, 1998). Berdasakan pengalaman-pengalaman pada krisis perbankan dapat dicermati pula bahwa krisis-krisis yang terjadi pada perbankan seringkali diawali dengan adanya perubahan kondisi lingkungan ekonomi makro yang bergerak dari kondisi stabil atau tumbuh positif ke arah resesi. Hal ini menguatkan pendapat Llewellin (2002) melalui ulasannya yang menyatakan bahwa setiap krisis perbankan merupakan hasil dari interaksi antara kondisi ekonomi, keuangan dan struktur lembaga yang sedang melemah.

Bertolak dari pandangan Llewellin (2002), dapat dicermati bahwa kondisi makro ekonomi dan situasi keuangan makro merupakan faktor yang kemungkinan memiliki peran dominan dalam menentukan kinerja perbankan yang sehat. Namun demikian, disebutkan pula bahwa struktur kelembagaan yang sedang melemah mungkin juga memberikan kontribusi bagi krisis perbankan. Dalam hal ini, perbankan memiliki kemungkinan untuk mengalami kesulitan likuiditas atau bahkan kebangkrutan yang disebabkan karena tingginya angka pinjaman yang mengalami kemacetan (Castro, 2013). Dapat dilihat disini bahwa struktur dalam kelembagaan bank yang sedang melemah seperti misalnya lemahnya sistem pengawasan kredit atau pelonggaran terhadap syarat-syarat kredit, dapat merupakan pemicu terjadinya krisis perbankan.

Penelitian ini menguji kondisi ekonomi makro yang dalam penelitian ini dikategorikan sebagai faktor ekternal dan manajemen proses risiko kredit yang dikategorikan sebagai faktor internal dalam mempengaruhi tingkat non performing loans (NPL) pada industri perbankan. Hal ini bermakna bahwa penelitian ini berupaya untuk mengisi gap atas berbagai penelitian yang menyebutkan bahwa NPL pada perbankan dipengaruhi oleh kondisi ekonomi makro (Castro, 2013; Demirguc-Kunt \& Detragiache, 1998; Aviliani et al., 2015) dengan menambahkan proses manajemen kredit sebagai cerminan kondisi internal struktur kelembagaan perbankan sebagai variabel mediasi berdasarkan teori beberapa peneliti terdahulu, diantaranya Llewellin (2002) dan Abid et al. (2014).

Survey Bank Indonesia tahun 2016, menunjukkan adanya peningkatan pertumbuhan kredit sebesar 2,2 persen (yoy) pada tahun 2016 dari realisasi tahun 2015 sebesar 9,8 persen (yoy). Optimisme peningkatan pertumbuhan kredit didasari dengan peningkatan dari total kredit yang meningkat dari 1.183.333 milliar rupiah pada tahun 2014 menjadi 1.234 .742 milliar rupiah pada tahun 2015 atau mengalami peningkatan sebesar $4,16 \%$. Namun demikian, peningkatan penyaluran kredit ini ternyata juga diikuti dengan meningkatnya tingkat NPL (gambar 1). Realitas ini memunculkan perspektif tentang diperlukannya sebuah langkah penanganan manajemen risiko kredit yang lebih efektif karena tingginya NPL dipandang sebagai indikator buruknya kinerja perbankan dan berdampak negatif bagi perekonomian suatu negara, terutama negara yang sedang membangun seperti Indonesia. Bila permasalahan kredit perbankan yang mengalami gagal bayar cukup tinggi maka akan berdampak pada terjadinya krisis perbankan (Abid et al., 2014), yang berpotensi pada terganggunya sistem keuangan dan selanjutnya dapat berakibat pada krisis finansial (Mankiew, 2014). 


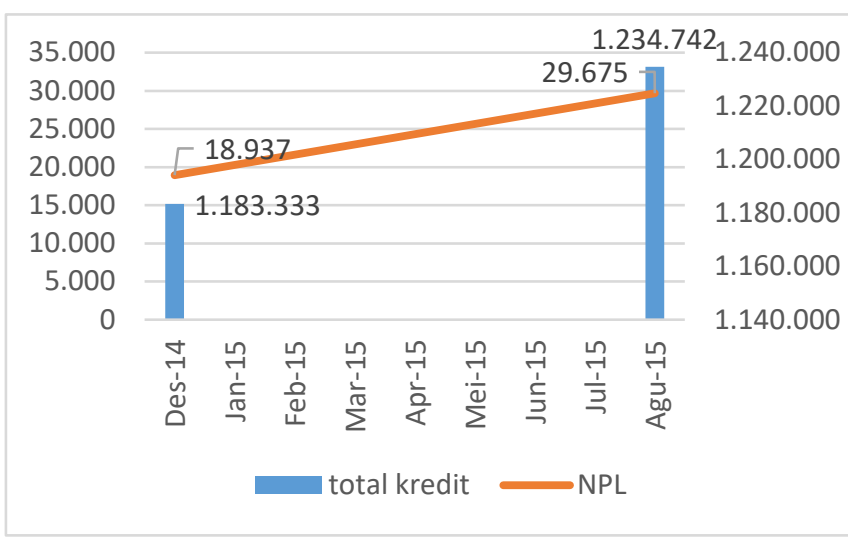

Gambar 1

Pertumbuhan Total Kredit dan NPL di Indonesia Tahun 2015

Sumber: Bank Indonesia (2016)

Disamping risiko kredit sebagaimana telah dikemukakan di atas, beberapa penelitian menunjukkan bahwa NPL juga dipengaruhi oleh faktor ekonomi makro (Dimitrios et al., 2016; Louzis et al., 2012; Abid et. Al., 2014). Dimitrios et al. (2016) melakukan studi tentang determinan NPL yang dibedakan atas tiga kelompok faktor. Faktor yang pertama adalah kondisi internal kreditur yang dalam hal ini menunjukkan tingkat efisiensi manajerial bank. Faktor ini diukur melalui indikator tingkat ROA dan ROE institusi perbankan yang diteliti. Faktor kedua adalah faktor yang terkait dengan kondisi ekonomi makro yang diukur melalui rasio pengangguran, tingkat pertumbuhan ekonomi, dan tingkat inflasi yang berlaku. Sedangkan faktor ketiga yang dianggap mempengaruhi NPL adalah faktor-faktor yang terkait dengan regulasi perpajakan yang dalam hal ini diukur melalui tarif pajak yang berlaku dan besaran anggaran pemerintah yang berasal dari penerimaan pajak. Namun demikian, telaah lebih lanjut dan dalam setting yang berbeda tentang pengaruh kondisi makro ekonomi terhadap NPL perlu tetap dilakukan karena beberapa penelitian yang lain menunjukkan adanya perbedaan tingkat pengaruh dalam kategori kredit yang berbeda (Louzis et al., 2012).

Berdasarkan atas pemaparan di atas, penelitian ini bertujuan untuk menguji dan menganalisis sebuah model yang menggambarkan hubungan antara kondisi ekonomi makro, proses manajemen risiko kredit, dan tingkat NPL. Analisis dilakukan dalam konteks kredit yang dikeluarkan oleh bank komersial dengan berfokus pada pandangan atau persepsi para analis kredit pada bank komersial terhadap variabel-variabel yang diteliti. Studi persepsi analis kredit terhadap variabel-variabel yang diteliti ini merupakan studi yang menarik mengingat banyak studi tentang hubungan antara kondisi ekonomi makro dengan kinerja perbankan selama ini lebih banyak menggunakan data sekunder time series. Persepsi para analis kredit terhadap kondisi ekonomi makro ini menjadi pokok bahasan yang krusial mengingat rekomendasi dari analis kredit merupakan poin terpenting bagi pengambil keputusan untuk memberikan kredit terhadap debitur.

Penelitian ini merupakan studi kasus di Bank X. Penelitian terhadap analis pada Bank X ini menarik untuk dilakukan karena kondisi yang dialami oleh bank ini memiliki kesamaan dengan gap yang terjadi antara teori dan praktik sebagaimana telah dikemukakan di atas. Pandangan Castro (2013) dan Demirguc-Kunt \& Detragiache (1998) menyebutkan bahwa terdapat korelasi yang negatif antara kondisi ekonomi makro dengan tingkat risiko kredit dan krisis perbankan. Artinya, jika kondisi makro ekonomi membaik dan menguntungkan, maka akan mendorong pertumbuhan kredit dengan tingkat risiko gagal bayar yang rendah. Pada sisi yang lain, data yang tersedia pada Bank Indonesia (2016) sebagaimana tertuang pada gambar 1 menunjukkan kondisi tahun 2015 yang mengalami peningkatan jumlah kredit, tetapi diikuti pula oleh peningkatan NPL. Sementara itu rilis Kementerian Keuangan menyebutkan bahwa kondisi ekonomi makro dan kinerja APBN pada tahun 2015 relatif baik (www.kemenkeu.go.id/berita). Dalam analisis jangka pendek untuk tahun 2015, kondisi di Indonesia ini mengandung arti bahwa pada kondisi ekonomi makro yang relatif baik, jumlah kredit melalui perbankan mengalami kenaikan, namun tingkat NPL juga semakin tinggi. Dalam konteks ini berarti kondisi ekonomi makro akan berkorelasi secara positif dengan tingkat NPL.

\section{LATAR BELAKANG TEORI DAN HIPOTESIS \\ Kondisi Ekonomi Makro dan Proses Manajemen Kredit}

Ekonomi makro merupakan bagian dari kajian bidang ilmu ekonomi yang di dalamnya mempelajari bagaimana mekanisme kerja perekonomian sebagai suatu sistem kerja secara menyeluruh (Samuelson dan Nordhaus, 1996). 
Pokok permasalahan dalam studi ekonomi makro adalah masalah stabilisasi ekonomi. Dalam hal ini, lembaga keuangan khususnya perbankan menjadi sektor penting dalam mewujudkan stabilitas dan pertumbuhan ekonomi suatu negara. Beberapa krisis keuangan dunia yang baru-baru ini berlangsung telah menunjukkan bahwa krisis perbankan dapat menjadi pengganggu tatanan sebuah perekonomian (Agnello \& Sousa, 2011). Hal ini telah menarik penelitian-penelitian di bidang ilmu ekonomi untuk memahami faktor-faktor yang berpotensi memicu krisis perbankan. Diantara berbagai hipotesis tentang penyebab krisis perbankan, kondisi ekonomi makro dianggap sebagai faktor yang memainkan peran penting atas krisis perbankan ini (Castro, 2013).

Dalam proses perekonomian modern, bank merupakan salah satu bentuk badan usaha yang tugas utamanya sebagai lembaga perantara keuangan (financial intermediaries), dimana perantara keuangan ini berarti menyalurkan dana dari pihak yang kelebihan dana kepada pihak yang membutuhkan dana (Dendawijaya, 2003). Dalam hal ini, pemberian kredit merupakan salah satu aktivitas paling penting bagi dunia perbankan, disamping aktivitas utama lainnya untuk menghimpun dana dari masyarakat yang berupa tabungan. Dalam konteks ini, Heffernan (2005) menyebutkan bahwa ketersedian produk tabungan dan kredit menjadi pembeda usaha perbankan dari jasa keuangan lainnya. Dalam Undang-undang Negara Republik Indonesia Nomor 10 Tahun 1998 dijelaskan tentang pengertian kegiatan perbankan yaitu usaha perbankan yang meliputi tiga kegiatan, terdiri dari penghimpunan dana, penyaluran dana, dan pemberian jasa bank lainnya. Penghimpunan dan penyaluran dana merupakan kegiatan pokok bank dalam menjalankan peran utamanya sebagai lembaga intermediasi. Selain menjalankan fungsi utamanya, perbankan juga memiliki peran yang strategis bagi perkembangan ekonomi suatu negara (Aviliani et.al, 2015).

Dalam menjalankan peran utamanya, dunia perbankan malakukan dua kegiatan yaitu deposit (tabungan) dan lending (kredit). Heffernan (2005) menjelaskan bahwa deposit merupakan sebentuk kewaijiban (liabilities) bagi perbankan, sehingga perlu dikelola dengan baik jika perbankan menginginkan maksimalisasi keuntungan. Pada sisi yang lain, Miskhin (2004) menjelaskan bahwa kredit merupakan core business dan merupakan penghasil aset produktif dalam dunia perbankan.

Terdapat tiga pendekatan secara umum dalam pemberian kredit, yaitu pendekatan struktural, pendekatan statistik, dan pendekatan penilaian ahli atau penilaian subjective. Pendekatan ketiga yang dipandang oleh Ibtissem dan Bouri (2013) sebagai pendekatan yang lebih baik mensyaratkan pemberi kredit untuk melakukan penialaian terhadap calon penerima kredit yang layak berdasarkan pengalaman dari pemberi kredit sesuai dengan aturan evaluasi kredit yang tertuang dalam prinsip 5C. Dikatakan sebagai pendekatan yang lebih baik dari dua pendekatan lainnya karena pendekatan subjective ini tidak hanya berdasar pada history data tetapi juga pada data internal lain dari calon debitur yang tidak terlalu sulit untuk mendapatkannya (Ibtissem dan Bouri, 2013), misal kecukupan modal, nilai asset, kinerja usaha yang sedang dijalankan, dan informasi lain terkait dengan calon debitur.

Namun, dalam keputusan pemberian kredit kedekatan pelanggan dengan manajer dan sejarah kredit yang baik juga berpengaruh (Heffernan, 2005). Setelah memberi keputusan tersebut, pemberi keputusan harus bertanggungjawab dan menanggapi tuntutan untuk kredit yang timbul dari pelanggan yang mendadak berubah karena adanya fleksibelitas yang muncul (Rose dan Hudgins, 2013). Untuk memberi keputusan bahwa seorang nasabah ini berhak memperoleh kredit digunakkan berbagai metode, salah satunya adalah prinsip 5C (Karsh, 2014). Peavler (2013) dan Sinkey (2002) menjelaskan bahwa prinsip 5C merupakan cara evaluating credit worthiness dengan menggunakan beberapa macam faktor yang dikategorikan secara umum, yaitu Capacity, Capital, Collateral, Conditions, dan Character. Prinsip ini muncul dikarenakan banyaknya pengajuan kredit dari nasabah. Persyaratan kredit ini menurut Ross, Westerfield \& Jordan (2008) menentukan jangka waktu kredit dan suku bunga yang akan diberikan. Jangka waktu kredit mengacu pada periode waktu atas kredit yang diberikan. Panjang periode kredit dipengaruhi oleh nilai jaminan, risiko kredit, dan persaingan pasar. Moti, et al (2012) menjelaskan bahwa dalam pemberian kredit mengetahui nasabah sesuai prinsip $5 \mathrm{C}$ dapat menghindari terjadinya NPL.

Mohamad et al. (2015) menemukan bahwa manajemen risiko kredit memiliki peranan yang penting dikarenakan dalam pembuatan 
keputusan keuangan memiliki risiko kecil. Dalam hal ini juga membantu bank memiliki sistem keamanan two-dimension atas manajemen risiko kredit. Selama membuat keputusan pembiayaan, dibutuhkan informasi tentang pelanggan, dimana tiap bank memiliki prioritas yang berbeda. Dalam penelitian Mohamad et al. (2015) ini terdapat 5 responden, 4 diantaranya menutamakan peniliaian berdasarkan character yang dimiliki peminjam dan 1 berdasarkan collateral.

Kerangka konseptual yang dikembangkan oleh Richard et al. (2008) dalam setting industri perbankan komersial di Tanzania juga menunjukkan pentingnya sistem manajemen risiko kredit untuk mengurangi risiko gagal bayar pada industri perbankan. Dalam pandangan Richard et al. (2008), prinsip 5C merupakan faktor penting dalam pengelolaan risiko kredit perbankan, namun demikian, dianggap belum mencukupi untuk mengurangi risiko gagal bayar secara optimal. Dengan demikian, faktor lain diperlukan sebagai pelengkap terhadap prinsip 5C yang merupakan assessment dalam keputusan pemberian kredit. Dalam hal ini, proses manajemen risiko kredit harus mencakup tidak hanya aspek assessmentnya saja, tetapi harus mempertimbangkan pula aspek monitoring dan supervisi, serta aspek kontrol terhadap kinerja debitur. Dengan demikian, maka proses manajemen risiko kredit dipandang sebagai variabel yang lebih dapat dikontrol untuk menekan angka nonperforming loan pada industri perbankan dibandingkan dengan variabel ekonomi makro (Louzis et al., 2012; Dimitrios et al., 2016; Abid et al., 2013).

Hipotesis 1: Kondisi ekonomi makro berpengaruh terhadap proses manajemen risiko kredit.

\section{Kondisi Ekonomi Makro dan Tingkat NPL}

Dalam konteks perekonomian sebuah negara, institusi perbankan, yang dalam konteks penelitian ini adalah bank-bank komersial, memiliki peran yang krusial terutama bagi pembangunan perekonomian di negara berkembang. Hal ini disebabkan karena banyak pelaku ekonomi kecil dan menengah di negaranegara sedang membangun ini tidak memiliki akses terhadap pasar modal, sehingga keberadaan bank-bank komersial sangat diperlukan untuk memberikan dukungan pendanaan. Beberapa penelitian terdahulu yang telah dilakukan menunjukkan bahwa keberadaan bank-bank komersial yang berfungsi dengan baik dapat mempercepat pertumbuhan ekonomi, sementara yang tidak berfungsi dengan baik akan menghambat kemajuan ekonomi bahkan memperburuk kemiskinan pada negara yang sedang membangun (Richard et al., 2008).

Louzis et.al (2012) mengemukakan satu diantara beberapa faktor penentu timbulnya NPL adalah faktor Ekonomi Makro. Dalam beberapa literatur yang membahas mengenai kondisi ekonomi dan dampaknya terhadap kualitas kredit menjelaskan terdapat fase dimana NPL relatif rendah serta relatif meningkat. Secara sederhana dapat dijelaskan bahwa pada saat ekonomi mengalami reses maka terdapat indikasi peningkatan NPL begitu juga sebaliknya. Peningkatan NPL diakibatkan berkurangnya seluruh kegiatan konsumsi ataupun investasi yang berakibat menurunnya kualitas peminjam.

Lawrence (1995) sebagaimana dikutip oleh Louzis et.al (2012) menjelaskan tentang teori model life-cycle consumption. Model ini menyatakan bahwa calon peminjam/ peminjam dengan pendapatan rendah masuk dalam kategori yang cukup berisiko. Teori ini berpendapat bahwa kemungkinan suatu kredit mengalami gagal bayar tergantung pada pendapatan dan tingkat pengangguran dan disebabkan pula oleh tingginya ketidakpastian mengenai kondisi ekonomi di masa yang akan datang dan suku bunga kredit.

Banyak penelitian terdahulu yang menunjukkan fakta bahwa kondisi ekonomi makro sebuah negara memiliki peran yang penting sebagai determinan kinerja institusi perbankan yang beroperasi pada sistem keuangan negara tersebut. Hasil penelitian Aviliani et al. (2015) menunjukkan bahwa kondisi ekonomi makro memiliki pengaruh yang cukup kuat dalam menentukan kinerja institusi perbankan di Indonesia. Hasil penelitian tersebut konsisten dengan teori-teori keuangan makro yang menyebutkan keterkaitan variabel ekonomi makro dengan kinerja sektor perbankan. Indikator ekonomi makro yang sering digunakan untuk melihat pengaruhnya terhadap kinerja perbankan diantaranya adalah suku Bunga domestik, nilai tukar, dan aktivitasaktivitas di pasar modal (Aviliani et al., 2015).

Hipotesis 2: Kondisi ekonomi makro berpengaruh positif terhadap NPL 


\section{Proses Manajemen Risiko Kredit sebagai Determinan NPL}

Beberapa penelitian terdahulu menunjukkan adanya peran penting dari manajemen risiko kredit yang efektif guna membantu mengurangi kemungkinan kegagalan dan membatasi ketidakpastian pencapaian kinerja keuangan yang diperlukan (e.g. Llewellin, 2002; Abid et al., 2014). Sebagian besar penelitian mendukung gagasan bahwa adanya hubungan positif antara manajemen risiko kredit yang efektif dan profitabilitas bank. Sebelum mendiskusikan tentang pengaruh manajemen kredit terhadap keuntungan bank, batasan tentang definisi manajemen kredit perlu untuk diperjelas. Terdapat beberapa definisi yang diberikan tentang manajemen kredit oleh para ahli ekonomi. Mirach (2010), sebagai contoh, menjelaskan bahwa manajemen kredit merupakan pelaksanaan dan maintance dari beberapa kebijakan dan prosedur untuk meminimalkan modal yang terikat dengan debitur dan untuk meminimalkan kredit macet. Dapat dikatakan bahwa manajemen kredit merupakan pengelolaan keuangan dengan tujuan agar kredit yang disalurkan menjadi modal dari kreditur dan fungsi dari manajemen kredit juga mendorong efisien dimana kredit menjadi alat yang sangat baik untuk bisnis agar tetap stabil secara finansial.

Fungsi manajemen kredit ini tentu perlu didukung dengan adanya manajemen risiko kredit yang efektif. Lapteva (2009) menjelaskan bahwa manajemen kredit yang efektif tidak terlepaskan dari perkembangan teknologi perbankan, dimana akan meningkatkan kecepatan dalam membuat keputusan dan mendorong pengurangan biaya pengawasan risiko kredit. Risiko kredit merupakan salah satu risiko yang signifikan dalam kegiatan perbankan yang muncul akibat sifat kegiatan yang dilakukan institusi perbankan. Berkaitan dengan NPL ini, Gestel \& Baesems (2008) bahkan secara tegas menyebut bahwa gagal bayar dari sedikit nasabah dapat mengakibatkan kerugian yang sangat besar bagi bank.

Hakim dan Neaime (2001) mencoba untuk menguji pengaruh likuiditas, kredit, dan modal pada kinerja bank di bank Mesir dan Lebanon; mereka menemukan bahwa tindakan manajemen risiko merupakan kegiatan yang strategis sedemikian mempengaruhi penerapan aturan-aturan dan hukum perbankan. Njanike (2009) menemukan bahwa tidak adanya manajemen risiko kredit yang efektif menyebabkan terjadinya krisis perbankan, dan sistem manajemen risiko yang tidak memadai yang pada akhirnya menyebabkan krisis keuangan. Hasil penelitian Kithinji (2010) bahkan menunjukkan bahwa bagian yang lebih besar dari keuntungan bank tidak begitu dipengaruhi oleh variabel lain selain kredit dan kredit bermasalah. Selanjutnya Boahene, Dasah dan Agyei (2012) menguji hubungan antara risiko kredit dan profitabilitas bank, dan menemukan hubungan positif antara risiko kredit dan profitabilitas bank.

Beberapa penelitian lain juga menunjukkan tingkat urgensi manajemen risiko kredit untuk menunjang kinerja bank melalui kemampuannya untuk menekan NPL. Gakure, Ngugi, Ndwiga dan Waithaka (2012) menyelidiki efek dari teknik manajemen risiko kredit pada kinerja bank dari pinjaman tanpa anggunan. Mereka menyimpulkan bahwa risiko keuangan dalam organisasi perbankan mungkin mengakibatkan kendala kerugian pada kemampuan bank untuk memenuhi tujuan bisnisnya. Poudel (2012) mengeksplorasi berbagai indikator manajemen risiko kredit yang mempengaruhi kinerja keuangan bank menemukan bahwa indikator yang paling terpengaruh dalam kinerja keuangan perbankan adalah tingkat gagal bayarnya. Nawaz dan Munir (2012) menemukan bahwa manajemen risiko kredit berpengaruh terhadap profitabilitas bank, dan mereka menyarankan bahwa manajemen harus berhati-hati dalam menyiapkan kebijakan kredit yang mungkin tidak berpengaruh negatif terhadap profitabilitas. Idowu dan Awoyemi (2014) mengungkapkan bahwa manajemen risiko kredit berpengaruh terhadap profitabilitas bank. Dari berbagai penelitian tersebut dapat dilihat bahwa manajemen kredit yang benar dapat menyelamatkan bisnis perbankan tersebut dan dibutuhkan penilaian nasabah yang saksama, sehingga mengurangi kredit macet yang akan terjadi.

Hipotesis 3: Manajemen risiko kredit berpengaruh langsung terhadap NPL

\section{METODE PENELITIAN}

Penelitian ini berupaya mengungkapkan dan menjelaskan hubungan antara kondisi ekonomi makro, proses manajemen risiko kredit dan tingkat NPL, sedemikian penelitian ini dapat dikategorikan sebagai penelitian eksplanatori. Penelitian ini menggunakan 
metode deskriptif kuantitatif, yakni sebuah metode penelitian yang digunakan untuk memberikan gambaran mengenai suatu gejala atau fenomena secara lebih mendetail dan mendalam serta lebih menekankan pada pengujian teori-teori melalui pengukuran variabel-variabel penelitian dengan angka dan melakukan analisis data dengan prosedur statistik (Indriantoro dan Supomo, 2002). Dengan demikian, tujuan utama dari penelitian ini adalah menjawab pertanyaan tentang kondisi saat ini dari obyek yang diteliti yakni persepsi analis kredit pada Bank $\mathrm{X}$ terkait dengan kondisi makro ekonomi, proses manajemen kredit, dan NPL dalam rentang waktu tahun 2015-2016. Data yang digunakan dalam penelitian ini diambil secara langsung dari Bank $\mathrm{X}$, dengan metode pengumpulan data yang digunakan yaitu: (1) Kuesioner, yang memberikan tanggung jawab kepada responden untuk membaca dan menjawab pertanyaan, dan (2) Wawancara yang menggunakan pertanyaan secara lisan kepada responden. Dalam penelitian ini metode pengumpulan data utama yang digunakan adalah kuesioner, sedangkan untuk metode pengumpulan data yang lainnya seperti wawancara hanya ditujukan sebagai penunjang dalam melengkapi data utama.

Teknik pengambilan sampel dalam penelitian ini adalah dengan menggunakan metode pusposive sampling. Responden dalam penelitian ini adalah analis kredit pada Bank X dengan beberapa kriteria tertentu. Responden dengan kategori tertentu ini dipilih sebagai sampel karena peneliti menganggap bahwa responden-responden tersebut memiliki informasi yang diperlukan bagi penelitian (Hasan, 2000). Terdapat dua jenis sampel dalam purposive sampling yaitu judgement Sampling dan quota sampling. Pada jenis yang pertama sampel dipilih berdasarkan penilaian peneliti bahwa dia adalah pihak yang paling baik untuk dijadikan sampel penelitiannya. Sedangkan jenis kedua adalah bentuk dari sampel distratifikasikan secara proporsional, namun tidak dipilih secara acak melainkan secara kebetulan saja.

Dalam penelitian ini jenis purposive sampling yang digunakan adalah Judgement Sampling. Hal ini lebih didasarkan pada penilaian peneliti bahwa analis kredit merupakan pihak yang paling tepat untuk dijadikan sampel penelitiannya, karena mereka mempunyai rich information atas persoalan kredit pada institusi perbankan. Adapun yang dijadikan oleh peneliti sebagai kriteria sampel dalam penelitian ini adalah karyawan yang sedang bertugas atau pernah bertugas di bagian kredit dalam hal ini yaitu analis kredit. Penentuan jumlah sampel dalam penelitian ini menggunakan formula slovin (dalam Solimun, 2002) yang berdasarkan hasil perhitungan jumlah sampel ditentukan sebanyak 115,8 dan dibulatkan menjadi 116 responden. Selanjutnya responden yang dipilih adalah mereka yang pada kurun waktu tahun 2015-2016 melakukan assessment pengajuan kredit dan monitoring atas kredit yang sedang berjalan.

Penelitian ini menggunakan skala Likert dengan interval penilaian setiap jawaban responden dari angka 1 (sangat tidak setuju) sampai angka 5 (sangat setuju). Skala Likert sering digunakan sebagai perangkat untuk mengukur sikap, pendapat, dan persepsi seseorang atau sekelompok orang tentang fenomena sosial (Indriantoro dan Supomo, 2002). Variabel-variabel yang akan diukur berdasarkan persepsi responden dalam penelitian ini dikemukakan pada tabel 1, selanjutnya dijabarkan menjadi indikatorindikator yang dijadikan titik tolak dalam penyusunan butir-butir instrumen yang berupa pernyataan dalam kuesioner.

Teknik analisis yang digunakan dalam penelitian ini adalah analisis jalur, yakni metode yang digunakan untuk melihat dampak langsung atau tidak langsung dari suatu variabel yang dihipotesiskan sebagai peubah terhadap variabel yang diposisikan

Tabel 1.

Variabel, Indikator, dan pernyataan kuesioner

\begin{tabular}{|c|c|c|}
\hline Variabel & Indikator & Item \\
\hline \multirow{2}{*}{$\begin{array}{l}\text { Kondisi } \\
\text { Ekonomi } \\
\text { Makro (X) } \\
\text { (Abid et al., } \\
\text { 2014; Louzis } \\
\text { et al., 2012) }\end{array}$} & $\begin{array}{l}\text { Inflasi } \\
2015-2016\end{array}$ & $\begin{array}{ll}\text { 1. } & \text { Mendukung iklim } \\
\text { usaha sektor riil. } \\
\text { 2. } \\
\text { Tidak berpotensi } \\
\text { menimbulkan kredit } \\
\text { macet. } \\
\text { 3. } \\
\text { Indeks Harga } \\
\text { Konsumen relatif } \\
\text { stabil }\end{array}$ \\
\hline & $\begin{array}{l}\text { Suku } \\
\text { bunga } \\
2015-2016\end{array}$ & $\begin{array}{ll}\text { 4. } & \text { Mendukung iklim } \\
\text { usaha sektor riil } \\
\text { 5. } \\
\text { Mendorong } \\
\text { pertumbuhan usaha- } \\
\text { usaha baru. } \\
\text { 6. Mendorong } \\
\text { penawaran kredit } \\
\text { pada proyek } \\
\text { investasi dengan } \\
\text { harapan keuntungan } \\
\text { yang tinggi }\end{array}$ \\
\hline
\end{tabular}




\begin{tabular}{|c|c|c|}
\hline $\begin{array}{l}\text { Proses } \\
\text { Manajemen } \\
\text { Risiko }\end{array}$ & Assessment & $\begin{array}{ll}\text { 1. } & \text { Condition } \\
\text { 2. } & \text { Capital } \\
\text { 3. } & \text { Character } \\
\end{array}$ \\
\hline $\begin{array}{l}\text { (Richard et } \\
\text { al., 2008; } \\
\text { Abid et al., } \\
\text { 2014; Louzis } \\
\text { et al., 2012) }\end{array}$ & Monitoring & $\begin{array}{ll}\text { 4. Visitasi debitur } \\
\text { 5. } \\
\text { Monitoring terhadap } \\
\text { akun debitur } \\
\text { 6. Pembaruan file } \\
\text { kredit debitur }\end{array}$ \\
\hline $\begin{array}{l}\text { NPL (Y2) } \\
\text { (Louzis, } \\
\text { 2012) }\end{array}$ & $\begin{array}{l}\text { Risiko } \\
\text { NPL } \\
\text { Kredit } \\
\text { sedang } \\
\text { berjalan } \\
\text { 2015-2016 }\end{array}$ & $\begin{array}{l}\text { 1. } \begin{array}{l}\text { Penyaluran kredit } \\
\text { berisiko } \\
\text { menimbulkan NPL }\end{array} \\
\text { 2. Rekomendasi lelang } \\
\text { aset pada kredit } \\
\text { bermasalah. } \\
\text { 3. Tingkat } \\
\text { penghapusan kredit } \\
\text { berisiko meningkat }\end{array}$ \\
\hline
\end{tabular}

variabel-variabel yang diteliti. Untuk menjamin keabsahan instrument yang digunakan, maka dilakukan uji validitas dan reeliabilitas atas instrument dengan cara diuji cobakan sebanyak 20 kuesioner kepada responden. Idrus (2009) menyebutkan bahwa sebuah instrumen dapat dinyatakan valid apabila mampu benar-benar mengukur apa yang seharusnya diukur, serta dapat mengungkapkan data dari variabel yang akan diteliti secara tepat. Dalam penelitian kuantitatif dengan kuesioner sebagai instrument penelitian, validitas instrument dapat dinilai dengan menggunakan korelasi product moment dengan rumus sebagai berikut:

$$
r x y=\frac{N\left(\sum x y\right)-\left(\sum x \cdot \sum y\right)}{\sqrt{\left[N \sum x^{2}-\left(\sum x\right)^{2}\right]\left[N \sum y^{2}-\left(\sum y\right)^{2}\right]}}
$$

sebagai akibat. Konstruk dalam analisis jalur membedakan variabel yang diteliti menjadi dua jenis variabel yaitu eksogen yang merupakan variabel penyebab dan endogen atau variabel akibat. Pola hubungan langsung dan tidak langsung yang dikembangkan dalam analisis jalur harus didasarkan pada pertimbangan teoritis serta pengetahuan dari peneliti yang ditampilkan dalam bentuk gambar (path diagram) yang berfungsi membantu dalam melakukan konseptualisasi masalah yang lebih kompleks serta mempermudah dalam mengidentifikasi implikasi empiris maupun teoritis atas konstruk yang sedang diuji. Model model analisis jalur ini selanjutnya memiliki persamaan sub-struktural sebagai berikut:

$$
\begin{aligned}
& \mathrm{Y}_{1}=\rho \mathrm{y} 1 . \mathrm{X}+\varepsilon 1 \\
& \mathrm{Y}_{2}=\rho \mathrm{y} 2 \cdot \mathrm{X}+\rho \mathrm{y} 2 \mathrm{y} 1 \mathrm{Y}_{1}+\varepsilon 2
\end{aligned}
$$

Selanjutnya peranan variabel proses manajemen risiko kredit sebagai mediator hubungan antara variabel kondisi ekonomi makre dengan NPL dikalkulasi dengan rumus sebagai berikut:

Indirect Effect (IE) $\quad=\rho \mathrm{X} \times \rho \mathrm{Y}_{2} \mathrm{Y}_{1}$ Sedangkan pengaruh total dalam model (Total Effect) dikalkulasi dengan rumus sebagai berikut:

$$
\begin{aligned}
& \text { Total Effect }(\mathrm{TE}) \\
& \left.\rho \mathrm{Y}_{1} \mathrm{Y}_{2}\right)+\rho \mathrm{Y}_{2} \mathrm{X}
\end{aligned} \quad=\left(\rho \mathrm{Y}_{1} \mathrm{X} \quad \mathrm{x}\right.
$$

\section{HASIL DAN PEMBAHASAN}

\section{Uji Instrumen}

Penelitian ini menggunakan kuesioner sebagai instrumen untuk mendapatkan data penelitian berupa persepsi analis kredit terhadap

(Arikunto, 2006:170)

Setelah nilai $r$ tersebut diperoleh, maka langkah selanjutnya yaitu membandingkan antara hasil nilai $r$ perhitungan dengan tabel nilai kritis $r$ pada taraf signifikansi $(\alpha=0,3)$. Apabila nilai $r$ lebih besar dari 0,3 maka dikatakan valid, namun jika $r$ lebih kecil dari 0,3 maka dikatakan tidak valid. Sejumlah 20 sampel kuesioner yang telah diisi oleh responden diajukan untuk uji validitas ini dengan hasil yang disajikan dalam tabel 2 sebagai berikut.

Tabel 2

Hasil Uji Validitas Variabel

\begin{tabular}{|l|c|c|c|c|}
\hline \multicolumn{1}{|c|}{ Variabel } & Item & r hit & Sig. & Ket \\
\hline \multirow{3}{*}{ Kondisi } & $\mathrm{X}_{.1}$ & 0.781 & 0.000 & Valid \\
Ekonomi Makro & $\mathrm{X}_{.2}$ & 0.686 & 0.000 & Valid \\
$(\mathrm{X})$ & $\mathrm{X}_{.3}$ & 0.587 & 0.001 & Valid \\
& $\mathrm{X}_{.4}$ & 0.673 & 0.000 & Valid \\
& $\mathrm{X}_{.5}$ & 0.529 & 0.003 & Valid \\
& $\mathrm{X}_{.6}$ & 0.768 & 0.000 & Valid \\
\hline & $\mathrm{Y}_{1.1}$ & 0.481 & 0.007 & Valid \\
Proses & $\mathrm{Y}_{1.2}$ & 0.686 & 0.000 & Valid \\
Manajemen & $\mathrm{Y}_{1.3}$ & 0.708 & 0.000 & Valid \\
Risiko Kredit & $\mathrm{Y}_{1.4}$ & 0.475 & 0.008 & Valid \\
(Y) & $\mathrm{Y}_{1.5}$ & 0.588 & 0.001 & Valid \\
& $\mathrm{Y}_{1.6}$ & 0.604 & 0.000 & Valid \\
\hline \multirow{2}{*}{ Non Performing } & $\mathrm{Y}_{2.1}$ & 0.771 & 0.000 & Valid \\
Loan (Y) & $\mathrm{Y}_{2.2}$ & 0.755 & 0.000 & Valid \\
& $\mathrm{Y}_{2.3}$ & 0.867 & 0.000 & Valid \\
\hline
\end{tabular}

Hasil uji reliabilitas dalam penelitian ini menunjukkan bahwa kuesioner yang disusun reliabel dalam menghasilkan data yang diperlukan. Menurut Arikunto (2006) prinsip 
reliabilitas menunjuk pada pengertian bahwa suatu instrumen cukup dapat dipercaya untuk digunakan sebagai alat pengumpul data jika instrumen tersebut sudah baik. Dalam hal ini instrumen yang reliabel akan menunjukkan konsistensi atas data yang diperolehnya. Secara stratistik, cara menguji reliabilitas untuk keseluruhan item bisa dilakukan dengan menggunakan koefisien Alpha Cronbach dengan rumus:

$$
\mathrm{r}_{11}=\left[\frac{k}{k-1}\right]\left[1-\frac{\sum \sigma_{i}^{2}}{\sigma_{\text {tot }}^{2}}\right]
$$

Suatu instrumen dikatakan reliabel apabila memiliki koefisien reliabilitas sebesar $\geq 0,6$ (Maholtra 2009). Hasil uji reliabilitas ditampilkan dalam tabel 3 sebagai berikut:

Tabel 3

Hasil Uji Reliabilitas

\begin{tabular}{|l|c|c|}
\hline \multicolumn{1}{|c|}{ Variabel } & $\begin{array}{c}\text { Cronbach's } \\
\text { Alpha }\end{array}$ & Keterangan \\
\hline $\begin{array}{l}\text { Kondisi Ekonomi } \\
\text { Makro (X) }\end{array}$ & 0.757 & Reliabel \\
$\begin{array}{l}\text { Proses } \\
\text { Manajemen } \\
\text { Risiko Kredit }\left(\mathrm{Y}_{1}\right)\end{array}$ & 0.617 & Reliabel \\
$\begin{array}{l}\text { Non Performing } \\
\text { Loan }\left(\mathrm{Y}_{2}\right)\end{array}$ & 0.716 & Reliabel \\
\hline
\end{tabular}

\section{Diagram Hasil Analisis Jalur}

Gambar 2 menampilkan diagram hasil analisis jalur secara keseluruhan dalam penelitian ini, yang menunjukkan pengaruh signifikan dari masing-masing jalur yang dilewati ketiga variabel. Pengaruh variabel kondisi makro ekonomi terhadap proses manajemen risiko kredit adalah sebesar 0,402, pengaruh variabel kondisi makro ekonomi terhadap non-performing loan (NPL) sebesar 0,228 , dan pengaruh variabel proses manajemen risiko kredit terhadap NPL sebesar 0,311.

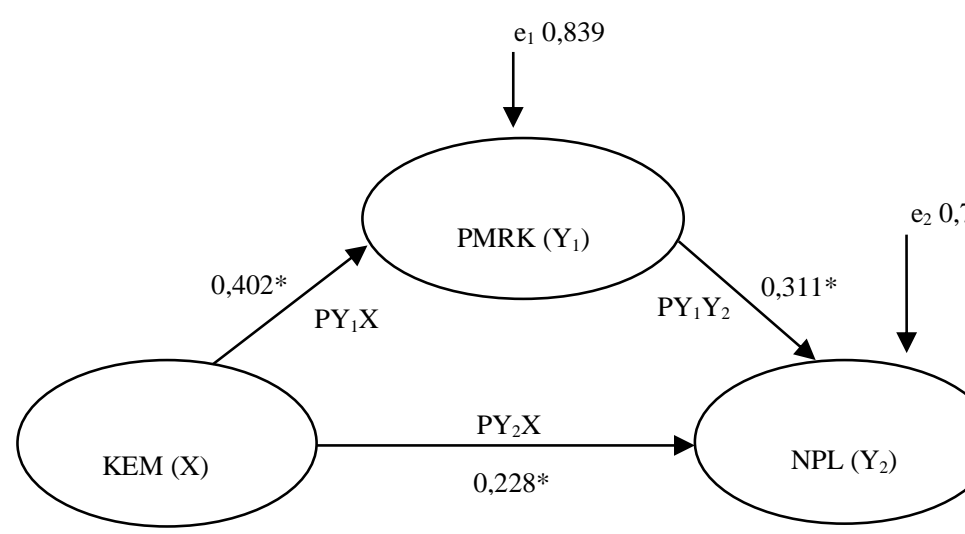

Gambar 2

Diagram Hasil Analisis Jalur

Keterangan:

KEM : Kondisi Ekonomi Makro

PMRK : Proses Manajemen Risiko Kredit

NPL : Non-Performing Loan

$\mathrm{PY}_{1} \mathrm{X}$ : Koefisien jalur variabel $\mathrm{X}_{1}$ ke $\mathrm{Y}_{1}$

$\mathrm{PY}_{2} \mathrm{X}$ : Koefisien jalur variabel $\mathrm{X}_{1}$ ke $\mathrm{Y}_{2}$

$\mathrm{PY}_{1} \mathrm{Y}_{2}$ : Koefisien jalur variabel $\mathrm{Y}_{1}$ ke $\mathrm{Y}_{2}$

Model analisis jalur memiliki kemampuan untuk memberikan penjelasan hubungan langsung dan tidak langsung atas variabel yang sedang diteliti. Dalam hal ini, pengaruh tidak langsung atau Indirect Effect (IE) mengukur besaran pengaruh variabel eksogen terhadap variabel endogen melalui variabel lain. Untuk mengetahui pengaruh tidak langsung (IE) variabel kondisi ekonomi makro terhadap variabel non-performing loan melalui variabel proses manajemen risiko kredit dapat dilakukan dengan cara mengalikan hasil pengaruh langsung pada jalur yang dilewati. Tabel 4 berikut menjelaskan perhitungan statistika untuk melihat pengaruh tidak langsung pada model yang diajukan.

Tabel 4

Pengaruh Tidak Langsung Variabel Kondisi Makro Ekonomi terhadap Non-performing loan melalui Proses Manajemen Risiko Kredit

\begin{tabular}{|c|c|c|c|}
\hline $\begin{array}{c}\text { Koefisie } \\
\mathbf{n}\end{array}$ & $\begin{array}{c}\mathbf{t} \\
\text { hitun } \\
\mathbf{g}\end{array}$ & $\begin{array}{c}\text { Signifikans } \\
\mathbf{i}\end{array}$ & $\begin{array}{c}\text { Keteranga } \\
\mathbf{n}\end{array}$ \\
\hline 0,126 & 2,663 & 0,009 & $\begin{array}{c}\text { Berpengaru } \\
\text { h Signifikan }\end{array}$ \\
\hline
\end{tabular}


Hasil analisis jalur pengaruh kondisi makro ekonomi (X) terhadap non-performing loan $\left(\mathrm{Y}_{2}\right)$ melalui proses manajemen risiko kredit $\left(\mathrm{Y}_{1}\right)$ dengan $\mathrm{t}$ hitung 2,663 dan lebih besar dari $\mathrm{t}$ tabel $(1,960)$ atau tingkat signifikansi 0,009 lebih kecil dari alpha 5\% menyatakan bahwa terdapat pengaruh yang dari kondisi makro ekonomi (X) terhadap non-performing loan $\left(\mathrm{Y}_{2}\right)$ melalui proses manajemen risiko kredit $\left(\mathrm{Y}_{1}\right)$.

Nilai koefisien 0,126 dan bertanda positif signifikan menyatakan bahwa bentuk pengaruh kondisi makro ekonomi (X) terhadap nonperforming loan $\left(\mathrm{Y}_{2}\right)$ melalui proses manajemen risiko kredit $\left(\mathrm{Y}_{1}\right)$ adalah berbanding lurus dan signifikan yang berarti bahwa peningkatan kondisi makro ekonomi $(\mathrm{X})$ tentu akan meningkatkan non-performing loan $\left(\mathrm{Y}_{2}\right)$ secara signifikan seiring dengan proses manajemen risiko kredit $\left(\mathrm{Y}_{1}\right)$ yang juga meningkat.

Disamping pengaruh langsung dan tidak langsung, dapat pula diidentifikasi pengaruh total dari model yang sedang diuji. Pengaruh total menunjukkan pengaruh secara menyeluh dari berbagai hubungan antar variabel yang sedang diteliti, dengan kata lain pengaruh total atau Total Effect (TE) digunakan untuk mengetahui seberapa besar pengaruh kaseluruhan hubungan antar variabel dalam sebuah model. Untuk mengetahui pengaruh total (TE) variabel kondisi makro ekonomi, proses manajemen risiko kredit dan nonperforming loan dapat dilihat melalui formulasi berikut:

$\mathrm{TE}=\left(\mathrm{PY}_{1} \mathrm{X} \times \mathrm{PY}_{2} \mathrm{Y}_{1}\right)+\mathrm{PY}_{2} \mathrm{X}$

$\mathrm{TE}=0,126+0,228$

$\mathrm{TE}=0,354$

Perhitungan pengaruh total menunjukkan angka sebesar 0,354. Angka tersebut bermakna bahwa pengaruh total variabel kondisi makro ekonomi dan proses manajemen risiko kredit terhadap non-performing loan sebesar 0,354.

\section{Ketepatan Model}

Ketepatan model hipotesis dan data penelitian diukur dari hubungan koefisien determinasi $\left(\mathrm{R}^{2}\right)$ di kedua persamaan. Hasil ketepatan model adalah:

$$
\begin{aligned}
\mathrm{R}^{2} \text { model } & =1-\left(1-\mathrm{R}_{1}^{2}\right)\left(1-\mathrm{R}_{2}{ }_{2}\right) \\
& =1-(1-0,161)(1-0,205) \\
& =1-(0,839)(0,795) \\
& =1-0,667
\end{aligned}
$$

$$
=0,333 \text { atau } 33,3 \%
$$

Berdasarkan atas hasil perhitungan ketepatan model yang menunjukkan angka sebesar 33,3\% ini, dapat diambil kesimpulan statistik bahwa kontribusi model untuk menjelaskan hubungan struktural dari ketiga variabel yang diteliti adalah sebesar $33,3 \%$ dan sisanya sebesar $66,7 \%$ dijelaskan oleh variabel lain yang tidak diajukan dalam model penelitian ini.

\section{Pengaruh kondisi ekonomi makro terhadap proses manajemen risiko kredit}

Hasil analisis jalur menunjukkan bahwa ketiga variabel yang diuji dalam penelitian ini saling berpengaruh secara signifikan. Variabel kondisi ekonomi makro memiliki pengaruh terhadap variabel proses manajemen risiko kredit yang ditunjukkan oleh nilai koefisien jalur $(\beta)$ sebesar 0,402 dan signifikan dengan probabilitas sebesar $0,000(p<0,05)$. Koefisien determinasi menunjukkan angka sebesar $16,1 \%$. Hasil uji ini menjelaskan bahwa terdapat pengaruh signifikan dari variabel kondisi ekonomi makro terhadap variabel proses manajemen risiko kredit dengan kontribusi sebesar $16,1 \%$, dan pengaruh langsung sebesar 0,402 . Sedangkan pengaruh sebesar $83,9 \%$ disebabkan oleh variabel-variabel lain diluar penelitian ini. Hasil penelitian ini menunjukkan bahwa variabel kondisi ekonomi makro berpengaruh terhadap proses manajemen risiko kredit.

Memperhatikan kompleksitas indikatorindikator ekonomi makro (mis. Bucur \& Dragomirescu, 2014) maka penelitian ini mengajukan dua indikator saja untuk mengukur kondisi ekonomi makro dalam konteks manajemen risiko kredit. Hal ini dilakukan karena penelitian ini mencoba untuk mengukur persepsi pihak yang berkepentingan terhadap informasi-informasi tentang kondisi ekonomi makro, dalam hal ini adalah para analis kredit sehingga digunakan hanya indikator-indikator yang paling sering digunakan oleh para analis. Penelitian yang dilakukan oleh Bucur dan Dragomirescu (2014) dilakukan dengan menelaah data sekunder time series selama kurun waktu enam tahun dari tahun 2008 sampai 2013. Dengan menggunakan menggunakan data sekunder maka Bucur dan Dragomirescu (2014) mampu untuk menganalisis lebih banyak indikator ekonomi makro. Namun demikian, penggunaan data sekunder pada umumnya bersifat lebih kaku dan tidak mampu merefleksikan persepsi dari 
pengambil keputusan (Richard etal., 2008). Sementara itu dengan cara yang berbeda, penelitian ini berupaya untuk mengungkap persepsi dari pengambil keputusan terkait dengan rekomendasi kredit dengan mengukur pandangan mereka terhadap kondisi ekonomi makro pada periode tertentu. Dengan demikian, untuk membuat ukuran persepsi responden lebih akurat, maka penelitian ini hanya mencoba untuk mengukur perspesi responden dengan menggunakan dua indikator saja yaitu tingkat inflasi dan tingkat suku bunga. Pembatasan penggunaan indikator untuk mengukur variabel kondisi ekonomi makro ini dapat dilakukan, sebagaimana dikemukakan oleh beberapa penelitian terdahulu (Salas \& Fumas, 2002; Abid et al., 2014; Aviliani et al., 2015) yang menggunakan sebagian saja dari berbagai indikator ekonomi makro yang dapat digunakan untuk menjelaskan variabel ekonomi makro.

Hasil analisis dalam penelitian ini menunjukkan bahwa, meskipun kontribusi kondisi ekonomi makro terhadap proses manajemen kredit adalah signifikan, namun para analis kredit pada rentang waktu 20152016 tidak terlalu ketat dalam mempertimbangkan kondisi ekonomi makro pada proses assessment dan evaluasi kredit. Artinya, ketika para analis ini hendak mengambil langkah pengetatan proses manajemen risiko kredit, terdapat pertimbangan-pertimbangan lain yang dianggap jauh lebih penting misalnya perubahan situasi dan stabilitas politik, keamanan, dan tuntutan untuk meningkatkan jumlah penyaluran kredit perbankan. Disamping asumsi-asumsi yang telah dikemukakan sebelumnya, para analis juga melihat pada kondisi kesehatan industriindustri tertentu yang sedang dinilai.

Hasil penelitian ini mendukung temuan dari penelitian yang dilakukan oleh Bekhet dan Eletter (2014) yang meneliti tentang model penilaian risiko kredit pada bank-bank komersial di Jordania. Perbedaan penelitian ini dengan penelitian Bekhet dan Eletter (2014) terletak pada indikator yang digunakan untuk menjelaskan faktor penentu risiko kredit. Pada penelitian Beket dan Eletter (2014) inflasi tidak dijadikan sebagai indikator untuk mengukur risiko kredit, sedangkan faktor tingkat suku bunga sebagai salah satu indikator yang digunakan, didapatkan memiliki pengaruh yang signifikan terhadap penilaian risiko kredit.
Meskipun hasil penelitian ini menunjukkan bahwa kondisi ekonomi makro yang direfleksikan melalui inflasi dan suku bunga memiliki pengaruh yang signifikan terhadap proses manajemen risiko kredit, penggunaan hanya dua indikator saja mungkin tidak cukup komprehensif untuk menjelaskan keseluruhan kondisi ekonomi makro. Dalam hal ini masih terdapat peluang untuk melakukan studi lanjutan baik secara parsial maupun secara simultan yang melibatkan indikator-indikator lain seperti GDP, indeks sumberdaya manusia, belanja pemerintah, hutang publik, pengangguran dan indikator lain untuk menjelaskan kondisi ekonomi makro sebagaimana telah dilakukan pada penelitian terdahulu (mis. Salas \& Fumas, 2002; Louziz et al., 2012; Abid et al., 2014; Aviliani et al., 2015) dengan menggunakan data time series dalam analisisnya. Untuk penelitian dengan menggunakan data primer pengukuran persepsi para pengambil keputusan, penelitian secara parsial dengan indikator ekonomi makro yang berbeda dapat dilakukan terhadap sekelompok responden yang sama, untuk selanjutnya hasil dari masing-masing studi dapat disintesiskan.

\section{Pengaruh kondisi ekonomi makro terhadap non-performing loan}

Variabel kondisi makro ekonomi memiliki pengaruh terhadap variabel non-performing loan yang ditunjukkan oleh nilai koefisien jalur $(\beta)$ sebesar 0,228 , signifikan dengan probabilitas sebesar $0,014 \quad(\mathrm{p}<0,05)$ dan koefisien determinasi sebesar $20,5 \%$. Hasil uji ini menjelaskan bahwa terdapat pengaruh signifikan dari variabel kondisi makro ekonomi terhadap variabel non-performing loan dengan kontribusi sebesar 20,5\%, dan pengaruh langsung sebesar 0,228 . Sedangkan pengaruh sebesar 79,5\% disebabkan oleh variabelvariabel lain diluar penelitian ini. Hasil penelitian ini menunjukkan bahwa variabel kondisi makro ekonomi berpengaruh terhadap non-performing loan.

Dalam penelitian terdahulu (mis. Aviliani et al, 2015; Washington, 2014) ditemukan bahwa kondisi makro ekonomi berpengaruh secara negatif terhadap kinerja kredit. Dalam hal ini apabila kondisi ekonomi makro membaik, maka terdapat kecenderungan bahwa non-performing loan akan menurun. Penting untuk dicatat dalam penelitian-penelitian terdahulu ini adalah indikator yang digunakan tidak hanya inflasi dan tingkat suku bunga, 
tetapi juga indikator lain seperti GDP, indeks sumberdaya manusia, belanja pemerintah, hutang publik, pengangguran, dan beberapa indikator lain. Temuan dalam penelitian ini menunjukkan bahwa kondisi ekonomi makro yang diukur dengan indikator inflasi dan tingkat suku buinga, berdasarkan persepsi para analis kredit sebagai responden, memiliki pengaruh yang positif signifikan terhadap nonperforming loan (NPL). Artinya, ketika tingkat inflasi dan tingkat suku bunga Pada periode tertentu mengalami kenaikan, maka terdapat kemungkinan naiknya tingkat prosentase NPL. Hasil wawancara dengan responden memperkuat hasil temuan dari peneltian ini bahwa dengan adanya kenaikan tingkat suku bunga khususnya pada Bank X akan memacu peningkatan NPL terutama di dalam sektor kredit produktif, karena sektor-sektor produktif merupakan sektor yang paling rawan dalam menyumbang NPL dikarenakan pada usahausaha sektor produktif memiliki penghasilan yang tidak tetap. Hasil temuan ini berbeda dengan temuan dari penelitian terdahulu yang dilakukan oleh Washington (2014) dan Mileris (2014) yang menyebutkan bahwa tingginya prosentase NPL lebih disebabkan karena diberlakukannya rezim floating rate pada sisi regulasi bank, sementara pada sisi lainnya banyak kredit konsumtif yang diambil oleh debitur dengan jumlah penghasilan tetap (fixed income). Dengan demikian ketika terjadi kenaikan suku bunga, maka debitur tidak memiliki cadangan dana yang cukup untuk mengantisipasi kenaikan tingkat suku bunga tersebut.

Selanjutnya perbedaan hasil penelitian ini dengan penelitian Aviliani (2015) dan penelitian Washington (2014) lebih banyak terletak pada kombinasi indikator-indikator yang digunakan uintuk mengukur variabel ekonomi makro. Pada penelitian Washington (2014) yang dilakukan di Kenya, sebagai contoh, menunjukkan bahwa faktor pertumbuhan GDP memiliki peran yang lebih dominan dibandingkan indikator ekonomi makro yang lain, sedemikian dalam uji regresi dengan menggunakan perangkat OLS ditemukan bahwa secara simultan variabel ekonomi makro memiliki pengaruh negatif terhadap NPL. Sedangkan hasil dari penelitian ini mendukung hasil uji parsial yang dilakukan oleh Washington (2014) yang menyebutkan bahwa tingkat inflasi dan tingkat suku bunga memiliki pengaruh yang positif signifikan terhadap NPL.

\section{Pengaruh Proses manajemen risiko kredit Terhadap Non-performing loan}

Variabel proses manajemen risiko kredit memiliki pengaruh terhadap variabel nonperforming loan yang ditunjukkan oleh nilai koefisien jalur $(\beta)$ sebesar 0,311 , signifikan dengan probabilitas sebesar $0,001(\mathrm{p}<0,05)$ dan koefisien determinasi sebesar 20,5\%. Hasil uji ini menjelaskan bahwa terdapat pengaruh signifikan dari variabel proses manajemen risiko kredit terhadap variabel non-performing loan dengan kontribusi sebesar 20,5\%, dan pengaruh langsung sebesar 0,311. Sedangkan pengaruh sebesar 79,5\% disebabkan oleh variabel-variabel lain diluar penelitian ini. Hasil penelitian ini menunjukkan bahwa variabel proses manajemen risiko kredit berpengaruh terhadap non-performing loan.

Beberapa penelitian terdahulu menunjukkan bahwa terdapat hubungan yang berlawanan (adverse effect) antara manajemen risiko kredit dengan non-performing loan. Penelitian yang dilakukan oleh Aduda dan Gitonga (2011) pada perbankan di Kenya menunjukkan bahwa semakin meningkat penilaian (assessment) atas sebuah kredit, maka dapat membantu menurunkan tingkat NPL. Demikian pula dengan penelitian yang dilakukan oleh Kodithuwakku (2015) pada bank-bank komersial di Srilanka menunjukkan hasil yang menunjukkan hubungan berlawanan antara manajemen risiko kredit dengan NPL. Kedua penelitian terdahulu ini (i.e. Aduda dan Gitonga, 2011 dan Kodithuwakku, 2015) menggunakan data primer dengan menyebar kuesioner terhadap responden kunci yang berhubungan langsung dengan proses pemberian kredit perbankan.

Satu hal yang menarik untuk dicatat dari penelitian yang dilakukan saat ini adalah temuan yang berbeda dari penelitian Aduda dan Gitonga (2011) dan Kodithuwakku (2015), dimana dalam penelitian ini ditemukan pengaruh yang positif antara proses manajemen risiko kredit dengan NPL. Hasil analisis statistika dalam penelitian ini menunjukkan terdapat pengaruh langsung yang signifikan dari variabel proses manajemen risiko kredit $\left(\mathrm{Y}_{1}\right)$ terhadap non-performing loan $\left(\mathrm{Y}_{2}\right)$. Koefisein beta pada hubungan proses manajemen risiko kredit terhadap non-performing loan menunjukkan angka sebesar 0,311 yang berarti 
bahwa peningkatan dalam suatu proses manajemen risiko kredit akan juga berpengaruh terhadap peningkatan NPL.

Berdasarkan hasil wawancara dengan responden dalam penelitian ini, pengetatan dalam setiap pengajuan kredit sepanjang tahun 2015-2016 tetap terus dilakukan. Hal ini mengacu pada regulasi yang dikeluarkan baik oleh Bank Indonesia (BI) maupun Otoritas Jasa Keuangan (OJK) selaku lembaga pengawas industri perbankan nasional yang meminta bank-bank komersial terus meningkatkan proses manajemen risiko atas kredit yang disalurkan. Pada saat yang bersamaan, manajemen Bank X menginginkan rasio NPL berada pada tingkat serendah mungkin, sedemikian pada kurun waktu tahun 2015-2016 banyak analis kredit yang sekaligus juga berfungsi sebagai evaluator kredit merekomendasikan untuk melelang aset-aset jaminan kredit yang berpotensi mengalami masalah yang lebih besar di kemudian hari. Keputusan yang diambil ini sejalan dengan persepsi para analis kredit yang meskipun menganggap kondisi ekonomi makro mendukung untuk ekspansi kredit, baik pada kredit produktif maupun kredit konsumtif, namun terhadap kredit yang telah berjalan, monitoring secara ketat semakin ditingkatkan dan masih mempersepsikan bahwa kredit-kredit yang telah disalurkan akan berpotensi meningkatkan NPL pada tahun 2015-2016.

\section{KESIMPULAN DAN SARAN Kesimpulan}

Hasil analisis dengan menggunakan model jalur pada penelitian ini sudah dapat dikatakan cukup baik. Namun demikian terdapat beberapa keterbatasan yang mungkin dapat dipenuhi oleh penelitian-penelitian dengan tema sejenis di masa mendatang. Beberapa keterbatasan tersebut antara lain adalah (1) Penelitian ini dilakukan dengan mengambil data primer berdasarkan persepsi responden yang mengambil keputusan terkait dengan proses pemberian kredit perbankan melalui kuesioner. Penggunaan kuesioner sebagai alat pengumpul data berdasarkan persepsi responden ini memiliki keterbatasan dalam hal jumlah variabel beserta indikator yang akan digali dari responden. Semakin banyak jumlah variabel beserta indikator-indikator yang diajukan dalam kuesioner, semakin tinggi pula kemungkinan terjadinya bias ketika responden mengisi kuesioner tersebut. Hal ini bisa terjadi karena beberapa sebab seperti tingkat kejenuhan, kompleksitas, dan kapasitas dalam memahami pernyataan atau pertanyaan dalam kuesioner. (2) Penelitian dilakukan dalam cakupan yang sempit, yaitu persepsi analis kredit pada Bank X. Meskipun cakupan sempit ini dapat mengurangi heterogenitas responden, namun hasil penelitian ini tidak dapat digeneralisasi secara luas terhadap para analis kredit di industri perbankan.

Hasil penelitian terhadap persepsi para analis kredit di Bank $\mathrm{X}$ terhadap variabel kondisi ekonomi makro dan proses manajemen kredit dalam kaitannya dengan NPL menunjukkan hasil sebagai berikut. Pertama, kondisi ekonomi makro didapatkan memiliki pengaruh signifikan terhadap proses manajemen risiko kredit dengan kontribusi sebesar $16,1 \%$, koefisien jalur $(\beta)$ sebesar 0,402 , serta probabilitas sebesar $0,000(\mathrm{p}<0,05)$. Kedua, kondisi ekonomi makro terbukti memiliki pengaruh signifikan terhadap nonperforming loan (NPL). Analisis statistik inferensial yang telah dilakukan menunjukkan adanya kontribusi sebesar 20,5\%, koefisien jalur $(\beta)$ sebesar 0,228 , serta probabilitas sebesar $0,000 \quad(p<0,05)$. Ketiga, proses manajemen risiko kredit ditemukan memiliki pengaruh signifikan terhadap non-performing loan (NPL) dengan kontribusi sebesar 20,5\%, koefisien jalur $(\beta)$ sebesar 0,311, serta probabilitas sebesar $0,001(\mathrm{p}<0,05)$.

\section{Saran}

Kondisi ekonomi makro memainkan peran yang penting bagi para pengambil keputusan dalam kegiatan perekonomian. Hasil penelitian ini menyimpulkan bahwa kondisi ekonomi makro berpengaruh terhadap proses manajemen risiko kredit. Dengan demikian diharapkan Bank $\mathrm{X}$ dapat memanfaatkan informasiinformasi yang berkaitan dengan indikatorindikator ekonomi makro dalam penyaluran kredit guna menekan tingkat NPL.

Penelitian yang sejenis dengan studi ini kedepannya perlu untuk mengisi keterbatasanketerbatasan yang ditemui oleh penelitian ini seperti keterbatasan penggunaan indikator untuk mengukur kondisi ekonomi makro berdasarkan persepsi responden yang dalam hal ini adalah para analis kredit. Penelitian sejenis selanjutnya seyogyanya dapat dilakukan dalam jangkauan yang lebih luas, tidak hanya sebatas pada analis kredit pada satu buah bank saja, 
tetapi dari berbagai bank yang berbeda dengan menggunakan metode yang tepat sehingga mampu mengurangi bias yang disebabkan perbedaan latar belakang budaya organisasi, visi, dan kepemimpinan di tempat bekerja.

\section{DAFTAR PUSTAKA}

Abid, L., Quertani, M. N., \& Zouari-Ghorbel, S. (2014). Macroeconomic and Bank-Specific Determinants of Household's NonPerforming Loans in Tunisia: a Dynamic Panel Data. Procedia Economics and Finance, 13( 2014 ), 58-68.

Aduda, J. \& Gitonga, J. (2011). The Relationship Between Credit Risk Management and Profitability Among the Commercial Banks in Kenya. Journal of Modern Accounting and Auditing, 7(9), 934946.

Agnello, L., Sousa, R. (2011). How do Banking Crises Impact on Income Inequality? NIPE Working Papers. University of Minho.

Aviliani, Siregar, H., Maulana, T. N. A., \& Hasanah, H. (2015). The Impact of Macroeconomic Condition on the Bank's Performance in Indonesia. Buletin Ekonomi Moneter dan Perbankan, 17(4), 379-402.

Bucur, I. A., \& Dragomirescu,S.E. (2014). The Influence of Macroeconomic Condition on Credit Risk. Studies and Scientific Researches 19, 94-95.

Castro, V. (2013). Macroeconomic Determinants of the Credit Risk in the Banking System: The Case of the GIPSI. Economic Modelling, 31, 672-683.

Demirguc-Kunt, A. \& Detragiache, E. (1998). The determinants of banking crises and developed countries. IMF Staff Papers, 45(1), 81-109.

Dendawijaya, L. (2003). Manajemen Perbankan. Jakarta: Ghalia Indonesia.

Dimitrios, A., Helen, L., \& Mike, T. (2016). Determinants of Non--performing Loans: Evidence from Euro-area Countries. Finance Research Letters 18(2016) 116119.

Heffernan, S. (2005). Modern Banking. New York: John Wiley and Sons.

Ibtissem, B., \& Bouri, A. (2013). Credit Risk Management In Microfinance: The
Conceptual Framework. ACRN Journal of Finance and Risk Perspectives, 2(1), 9-24

Kodithuwakku, S. (2015). Impact of Credit Risk Management on the Performance of Commercial Banks in Sri Lanka. International Journal of Scientific Research and Innovative Technology, 2(7), 24-29.

Llewellyn, D. (2002). An Analysis of the Causes of Recent Banking Crises. European Journal of Finance, 8, 152-175.

Louzis, D. P., Vouldis, A. T., \& Metaxas, V., L. (2012). Macroeconomic and Bank Specific Determinants of Non-performing Loans in Greece: A Comparative Study of Mortgage, Business and Consumer Loan Portfolios. Journal of Banking \& Finance 36 (2012), 1012-1027.

Mankiew, N. G. (2014). Principles of Macroeconomics. Seventh Edition. Stamford: Cengage.

Mileris, R. (2014). Macroeconomic Factors of Non-Performing Loans in Commercial Banks. Ekonomika 93(1), 22-39.

Mohamad, S. N. A., Basah, M. Y. A., Aziz, M. R A., Khairi, M. K F., Yusof, M. M., Laili, N. H. \& Sabri, H. (2015). Credit Evaluation Perspective of Dual-banking and FullFledge of Islamic Banking Approach in Malaysia: Current Practices and Issues. International Journal of Business and Social Science, 6(7), 169-185.

Richard, E., Chijoriga, M., Kaijage, E., Peterson, C., Bohman, H. (2008). Credit Risk Management System of a Commercial Bank in Tanzania. International Journal of Emerging Markets, 3(3), 323-332.

Rose, P. S., \& Hudgins, S. C. (2013). Bank Management \& Financial Services. New York: McGraw-Hill.

Salas, S. \& Fumas, V. S. (2002). Credit Risk in Two Institutional Regimes: Spanish Commercial and Savings Banks. Journal of Financial Services Research, 22(3), 179192.

Samuelson, P. A. \& Nordhaus, W. D. (2010). Macroeconomics. $19^{\text {th }}$ Ed. New York: McGraw-Hill.

Solimun. (2002). Structural Equation Modeling: Lisrel dan Amos. Malang: Universitas Negeri Malang. 
Washington, G. K. (2014). Effects of Macroeconomic Variables on Credit Risk in the Kenyan Banking System. International Journal of Business and Commerce, 3(9), 126. 